\title{
PENGARUH PERLAKUAN PEMECAHAN DINDING SEL Botryococcus braunii DAN Nannochloropsis MENGGUNAKAN MICROWAVE DAN SONIKATOR TERHADAP MINYAK YANG DIHASILKAN
}

\section{Effect of Cell Wall Disruption Treated by using Microwave and Sonicator of Botryococcus braunii and Nannochloropsis on The Amount of Oil Produced}

\author{
Sri Amini ${ }^{*}$, Diini Fitriani ${ }^{1}$, dan Sugiyono ${ }^{1}$ \\ ${ }^{1}$ Balai Besar Penelitian dan Pengembangan Pengolahan Produk dan Bioteknologi Kelautan dan Perikanan, \\ JI. K.S. Tubun Petamburan VI, Jakarta Pusat, Indonesia \\ * Korespondensi Penulis: aminisri@yahoo.co.id
}

Diterima: 10 Desember 2013; Disetujui: 3 Juni 2014

\begin{abstract}
ABSTRAK
Penelitian pengaruh pemecahan dinding sel Botryococcus braunii dan Nannochloropsis menggunakan microwave dan sonikator terhadap jumlah minyak yang dihasilkan telah dilakukan di Laboratorium BBP4BKP, Slipi, Jakarta. Botryococcus braunii dan Nannochloropsis telah dikultur di dalam bak fiber ukuran 1000 liter berisi air laut, diaerasi terus menerus dan diberi cahaya sinar matahari. Conwy media ditambahkan ke dalam media air laut sebagai nutrisi suplemen pada kultur. Biomassa Botryococcus braunii dan Nannochloropsis dipanen pada umur 4 hari, lalu dipecah dinding selnya menggunakan microwave dengan frekuensi $2540 \mathrm{MHz}$ dan sonikator dengan frekuensi $20 \mathrm{KHz}$. Minyak algae diekstraksi menggunakan pelarut heksan dilanjutkan dengan evaporasi menggunakan rotavapor. Hasil menunjukkan bahwa jumlah minyak dari Botryococcus braunii hasil pemecahan dinding sel menggunakan sonikator yaitu $22,24 \%$ dan microwave yaitu $7,92 \%$. Jumlah minyak Nannochloropsis dengan pemecahan dinding sel menggunakan sonikator adalah $11,92 \%$ dan microwave adalah 16,54\%. Ekstraksi minyak tanpa pemecahan dinding sel Botryococcu braunii sebesar 0,84\% dan Nannochloropsis sebesar 1,54\%. Asam lemak jenuh pada Botryococcus braunii antara lain asam stearat (18\%), palmitat $(5 \%)$, behenat (1\%), dan arachidat (4\%) dengan jumlah total $28 \%$. Sedangkan pada Nannochloropsis adalah asam stearat $(21 \%)$, palmitat $(9 \%)$, behenat $(1 \%)$, dan arachidat $(2 \%)$ dengan jumlah total $33 \%$.
\end{abstract}

KATA KUNCl: Botryococcus braunii, Nannochloropsis, microwave, sonikator, minyak

\section{ABSTRACT}

Study on the amount of oil produced of Botryococcus braunii and Nannochloropsis microalgae by treatments of cell wall disruption by microwave and sonicator have been done at Research and Development Center for Marine and Fisheries Product Processing and Biotechnology Laboratory, Slipi, Jakarta. Botryococcus braunii and Nannochloropsis were cultured in fiber flasks containing 1000 litre of sea waters, aerated and illuminated by sun shine fluorescent. Conwy medium was added to sea water culture medium as supplementary nutrients. The biomass of Botryococcus braunii and Nannochloropsis were harvested at 4 days culture, and the cell wall was broken using microwave at frequency of $2540 \mathrm{MHz}$ and sonicator at the frequency of $20 \mathrm{KHz}$. Oils algae was extracted using hexsane and than the solvent was evaporated using rotavapor. Results showed that the amount of oil extracion from Botryococcus braunii which the cell wall disrupted using sonicator was $22.24 \%$ and microwave was $7.92 \%$. The amount of Nannochloropsis disrupted using sonicator was $11.92 \%$ and microwave was $16.54 \%$. Oil extracted without disruption of cell walls from Botryococcus braunii was $0.84 \%$ and Nannochloropsis was $1.54 \%$. Saturated fatty acid in Botryococcus braunii were stearic acid (18\%), palmitic (5\%), behenic (1\%) and arachidic (4\%) with total amount of $28 \%$, while in Nannochloropsis were stearic acid (21\%), palmitic (9\%), behenic (1\%) and arachidic (2\%) with total amount of $33 \%$.

KEYWORDS: Botryococcus braunii, Nannochloropsis, microwave, sonicator, oils 


\section{PENDAHULUAN}

Botryococcus braunii dan Nannochloropsis adalah mikroalga hijau dari kelas Chlorophyceae yang hidup di lingkungan air tawar sampai air laut. Kandungan klorofil (zat hijau daun) mencapai 1,5-2,8\% yang terdiri atas klorofil a, b, dan c, sehingga di permukaan perairan tampak berwarna hijau-coklat kekuningan. Botryococcus braunii dan Nannochloropsis memiliki inti sel dan dinding sel yang keras bersifat non motil, yaitu pergerakannya sangat dipengaruhi oleh arus perairan. Botryococcus braunii kaya hidrokarbon hingga mencapai $15-76 \%$ berat kering. Hidrokarbon rantai panjang dalam bentuk minyak dari spesies ini dikenal dengan nama botryococcene dan sangat potensial sebagai sumber energi atau biodiesel (Kabinawa, 2008). Botryococcus braunii dan Nannochloropsis termasuk algae mikroskopik, berkembang biak sangat cepat dengan daur hidup relatif pendek (Panggabean, 1998).

Indonesia mempunyai perairan dangkal yang luas dengan intensitas sinar matahari yang cukup sepanjang tahun, sehingga sangat besar kemungkinannya untuk membudidayakan alga mikroskopik. Mikroalga mengandung minyak yang komposisinya mirip seperti tanaman darat. Hal yang menarik untuk dikembangkan adalah kandungan minyak dalam mikroalga pada spesies tertentu cukup tinggi, yaitu rata-rata $40 \%$. Kandungan minyak spesies Botrycoccus braunii dapat melebihi kandungan minyak tanaman darat penghasil minyak, seperti kelapa, jarak, dan sawit. Menurut Chisti (2007), kandungan minyak Tetraselmis sebesar $15-23 \%$, sedangkan Botrycoccus braunii sebesar $44,5-85 \%$ (Borowitzka, 1992). Kandungan minyak nabati yang tinggi mengindikasikan kandungan senyawa asam lemak yang tinggi dalam mikroalga. Semakin banyak kandungan asam lemak dalam suatu bahan, maka semakin besar pula biodiesel yang dihasilkan (Zuhdi \& Sukardi, 2005).

Jenis mikroalga Botryococcus braunii adalah satusatunya mikroalga yang menghasilkan hidrokarbon dalam jumlah yang cukup banyak, yaitu sekitar $80 \%$ dari berat keringnya. Hidrokarbon Botryococcus braunii terletak di luar selnya di dalam matriks koloni (Kabinawa, 2001). Botryococcus mampu menghasilkan hidrokarbon dengan rantai C23-C40, misalnya $n$-alkadiena dan $n$-alkena. Kemampuan ini membuat Botryococcus braunii amat potensial sebagai sumber bahan bakar cair terbarukan, menggantikan bahan bakar minyak fosil, seperti minyak bumi, gas, dan batu bara. Dengan menghasilkan senyawa hidrokarbon jenis alkena, mikroalga dapat dijadikan pilihan sebagai sumber energi masa depan yang dapat berperan dalam pengembangan bioenergi, terutama biohidrogen yang bersumber dari mikroalga perairan air tawar ataupun laut. Mikroalga yang terkenal sebagai penghasil hidrokarbon, sumber biodiesel ini, adalah diatom dan Chlorophyta, seperti Botryococcus braunii (Kabinawa, 2001).

Nannochloropsis juga merupakan ganggang mikroskopis dari kelas Chlorophyceae yang mempunyai kandungan minyak cukup tinggi. Menurut Borowtzka (1992) kelas Chlorophycae mempunyai kandungan minyak berkisar antara $1-70 \%$. Nannochloropsis cukup banyak dan melimpah di daerah tropis termasuk Indonesia, mudah dibudidayakan di seluruh hatchery sebagai pakan larva ikan, kekerangan dan biota laut lainnya. Oleh sebab itu selain jenis Botryococcus braunii perlu pula diketahui apakah jenis Nannochloropsis ini cukup potensial untuk dikembangkan sebagai bahan baku biofuel.

Produksi biodiesel dari mikroalgae meliputi 4 tahap penting yaitu kultivasi biomassa, pemisahan biomassa dari media, ekstraksi minyak dan transesterifikasi minyak menjadi produk akhir (Lee et al., 2010). Keempat tahapan ini sangat penting diperhatikan untuk diperoleh rendemen minyak dalam jumlah yang banyak. Ketangguhan dinding sel dan membran sel mikroalga membuat lipid tidak mudah diekstraksi sehingga dibutuhkan energi besar yang intensif untuk merusak sel tersebut (Lee et al., 2012).

Dari berbagai keuntungan yang dimiliki alga mikroskopik mempunyai potensi besar untuk dikembangkan sebagai bahan baku biofuel, namun perlu dilakukan penelitian lebih lanjut, khususnya berkaitan dengan teknik pemecahan dinding sel dan proses ekstraksi menggunakan pelarut untuk memperoleh jumlah minyak yang maksimum.

\section{BAHAN DAN METODE}

\section{Kultivasi dan Pemanenan Mikroalgae}

Kultivasi starter mikroalga Botryococcus braunii, dan Nannochloropsis dilakukan di dalam laboratorium menggunakan air laut dengan kadar garam $25 \mathrm{ppt}$ di dalam wadah ukuran 30 liter. Wadah-wadah ditempatkan pada suhu ruang terkontrol $\left(25^{\circ} \mathrm{C}\right)$ menggunakan cahaya lampu neon pada intensitas 2000 lux. Hasil kultivasi starter skala laboratorium kemudian ditebarkan pada kultur skala massal di luar ruangan dalam wadah kapasitas 1000 liter menggunakan air laut berkadar garam $25 \mathrm{ppt}$, aerasi terus menerus dan cahaya matahari untuk proses fotosintesis. Pada kultivasi skala laboratorium ataupun skala massal digunakan pupuk Conwy (Fogg \& Thake 
1987; Amini, 2004). Pertumbuhan sel mikroalga diamati kepadatan selnya menggunakan cara OhHama \& Miyachi (1992).

Pemanenan biomassa Botryococcus braunii dan Nannochloropsis dilakukan pada umur 4 hari kultivasi dengan cara mengendapkan/flokulasi biomassanya dengan penambahan $\mathrm{NaOH}$ sampai $\mathrm{pH}$ 9,0-11,0. Flokulan yang mengendap kemudian didiamkan selama 24 jam lalu disaring menggunakan kain satin atau filterbag. Hal tersebut dilakukan karena ukuran Botryococcus braunii, dan Nannochloropsis berkisar antara 3-5 $\mu \mathrm{m}$. Biomassa mikroalga dalam bentuk flokulan dinetralkan terlebih dahulu dengan asam menjadi $\mathrm{pH} 7,0-8,0$. Pengeringan biomassa Botryococcus braunii dan Nannochloropsis dengan cara penjemuran di atas kain satin. Kadar air dari biomassa mikroalgae kering dihitung berdasarkan metode AOAC (1999). Hasil panen biomassa mikroalgae tersebut dipersiapkan untuk dipecah dinding selnya menggunakan sonikator dan microwave sebelum diekstrak minyaknya.

\section{Cara Pemecahan Dinding Sel Mikroalgae}

Pemecahan dinding sel Botryococcus braunii dan Nannochloropsis menggunakan sonikator dilakukan dengan frekuensi $20 \mathrm{KHz}$ suhu mencapai $70{ }^{\circ} \mathrm{C}$. Sedangkan pemecahan Botryococcus braunii dan Nannochloropsis menggunakan microwave dilakukan dengan frekuensi $2540 \mathrm{MHz}$ suhu mencapai $90^{\circ} \mathrm{C}$.

Terpecahnya dinding sel dapat diketahui melalui foto scanning menggunakan alat SEM di Laboratorium LIPI Cibinong.

\section{Ekstraksi Minyak Mikroalgae}

Ekstraksi minyak dilakukan dengan modifikasi metode Algae Oil Extraction, com. 26/12/2006 (Banerjee et al., 2002; Anon., 2006; Dayananda et al., 2007), menggunakan pelarut heksana. Biomassa mikroalga dari jenis Botryococcus braunii dan Nannochloropsis yang telah dipecah dinding selnya diekstrak menggunakan n-heksana untuk mengeluarkan minyaknya (Gambar 1).

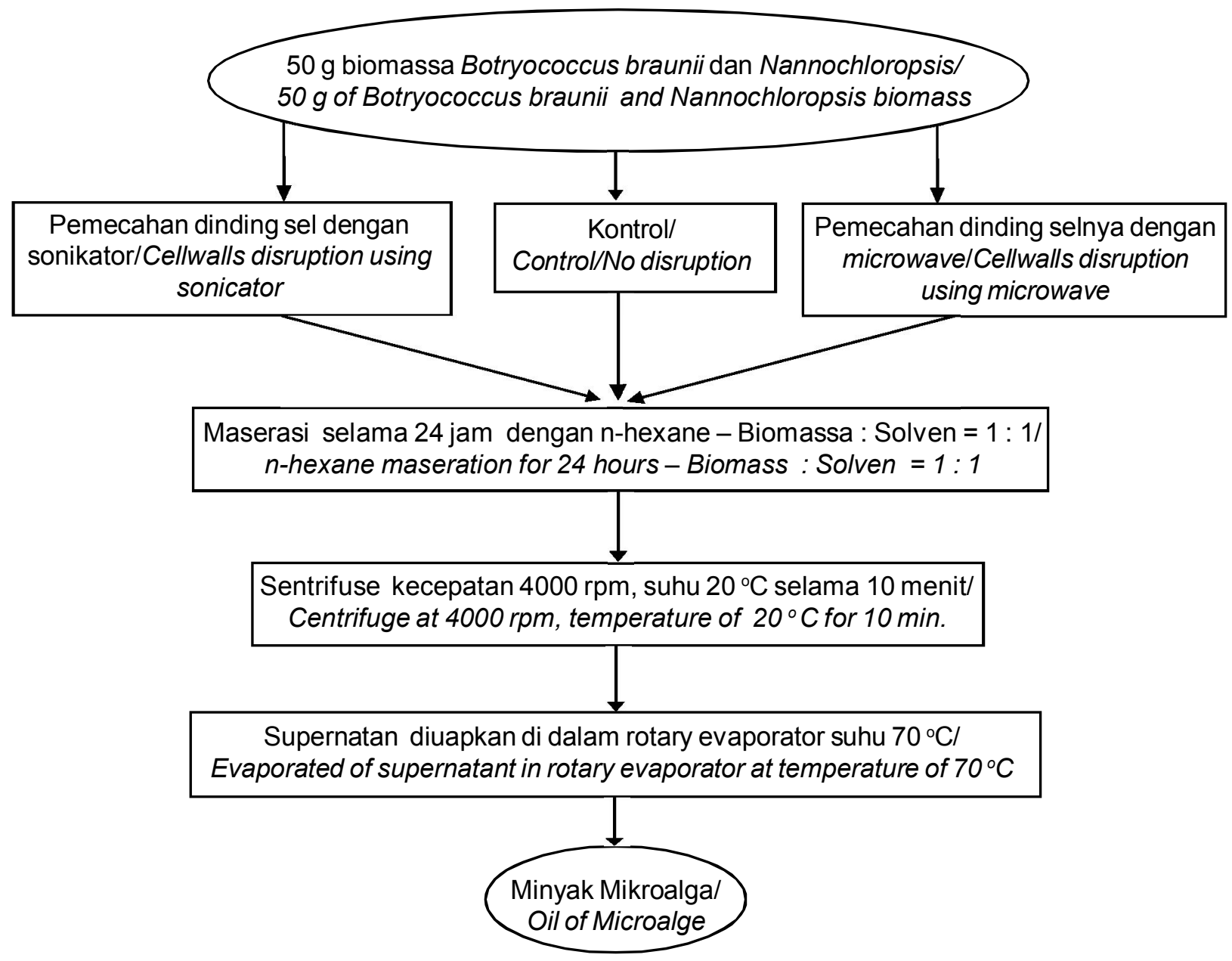

Gambar 1. Skema ekstraksi minyak mikroalga.

Figure. 1. Scheme of microalgae oils extractions. 


\section{Rancangan Penelitian}

Pada penelitian ini digunakan mikroalga jenis Botryococcus braunii dan Nannochloropsis yang dipecah dinding selnya menggunakan sonikator dan microwave dan yang tanpa pemecahan sebagai kontrol. Percobaan dilakukan dengan 4 kali ulangan.

\section{Parameter yang diamati}

Pada penelitian ini diamati parameter kepadatan sel selama kultivasi menggunakan haemocytometer pada mikroskop, terpecahnya dinding sel menggunakan SEM (Scanning Electron Microscop), jumlah minyak hasil ekstraksi (AOAC,1999) dan komposisi asam lemak menggunakan GCMS (Borowitzka, 1992 dan Puspita, 2009).

\section{HASIL DAN PEMBAHASAN}

\section{Kepadatan sel Botryococcus braunii dan Nannochloropsis}

Hasil kultivasi mikroalga di dalam media 1000 liter air laut yang dipanen pada umur 4 hari pemeliharaan, menghasilkan kepadatan sel Botryococcus braunii $\log 7,04 \mathrm{sel} / \mathrm{ml}$ dan Nannochloropsis adalah $\log 7,15$ $\mathrm{sel} / \mathrm{ml}$ (Gambar 2). Pemberian pupuk Conwy yang sama pada media kultivasi menghasilkan jumlah kepadatan sel berbeda. Hal ini sebab setiap spesies mikroalga mempunyai laju pertumbuhan yang berbeda. Pemanenan mikroalgae pada hari ke-4 kultivasi dilakukan karena kepadatan sel sudah mencukupi $(\log 7,0)$. Bila ditangguhkan pemanenannya maka pertumbuhan biomassa dapat mengalami penurunan sehingga kepadatan menjadi rendah bahkan mengakibatkan kematian. Hal ini disebabkan komposisi nutrient yang dibutuhkan oleh sel mikroalga di dalam media tumbuh sudah berkurang yang dapat mengakibatkan fase konstan (stasionary phase) menjadi lebih cepat dan diikuti fase kematian yang ditunjukkan dengan warna bening dan selnya menjadi hilang seketika (Amini, 2004). Pada penelitian ini pemanenan dilakukan pada fase exponensial. Sepanjang masa pertumbuhan exponensial koloni alga Botryococcus braunii memiliki warna hijau karena mengandung klorofil a dan $b$, serta memiliki kandungan hidrokarbon antara $20-33 \%$ dari berat tubuhnya (Brown, Knigth, and conwan, 1969; Wolf, 1983 dalam Nurhadiati, 2008) umumnya hidrokarbon yang dihasilkan memiliki jumlah karbon C27-C31 dan mayoritas berupa olein. Kultivasi dalam jumlah besar (volume media 1000 liter) yang dilakukan di luar ruangan mempunyai waktu pertumbuhan yang cepat dan maksimum pertumbuhannya hanya 7 hari. Bila dibandingkan kultivasi di dalam ruangan terkontrol dengan cahaya lampu neon pertumbuhannya dapat mencapai 2 sampai 3 minggu, dengan kepadatan optimum dapat mencapai $\log 8,0 \mathrm{sel} / \mathrm{ml}$ (Amini, 2005).

\section{Hasil Pemecahan Dinding Sel Botryococcus braunii dan Nannochloropsis}

Hasil pemecahan dinding sel maupun tanpa pemecahan dinding sel mikroalga (kontrol) yang diamati menggunakan SEM dapat dilihat pada Gambar 3-8. Sel mikroalga yang dipecah dinding selnya menggunakan microwave dan sonikator menunjukkan sel hancur seperti gumpalan putih yang terlihat jelas pada Gambar 4, 5, 7, dan 8. Sedangkan

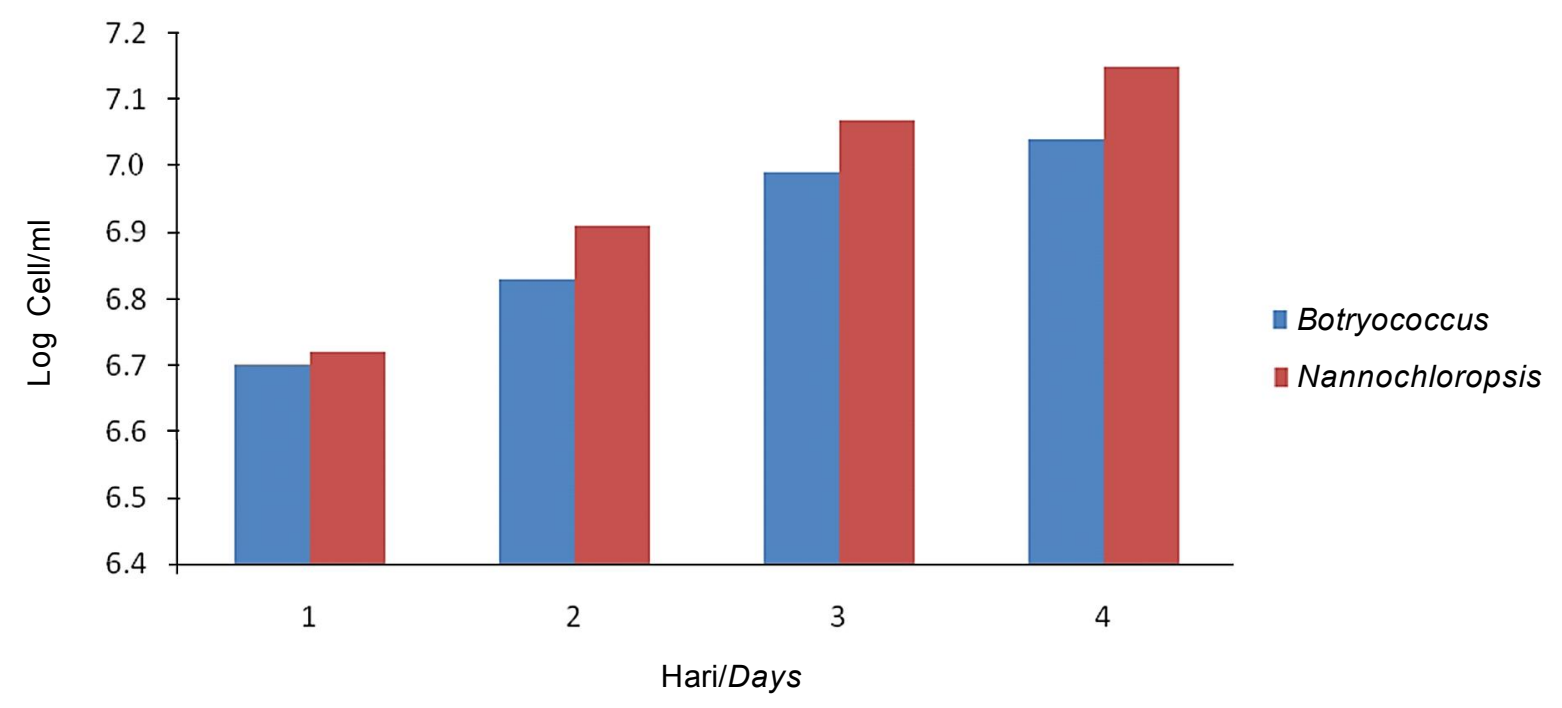

Gambar 2. Kepadatan sel mikroalgae di dalam volume media air laut (1000 liter). Figure 2. Cell density of microalgae in sea wáter (1000 litre). 


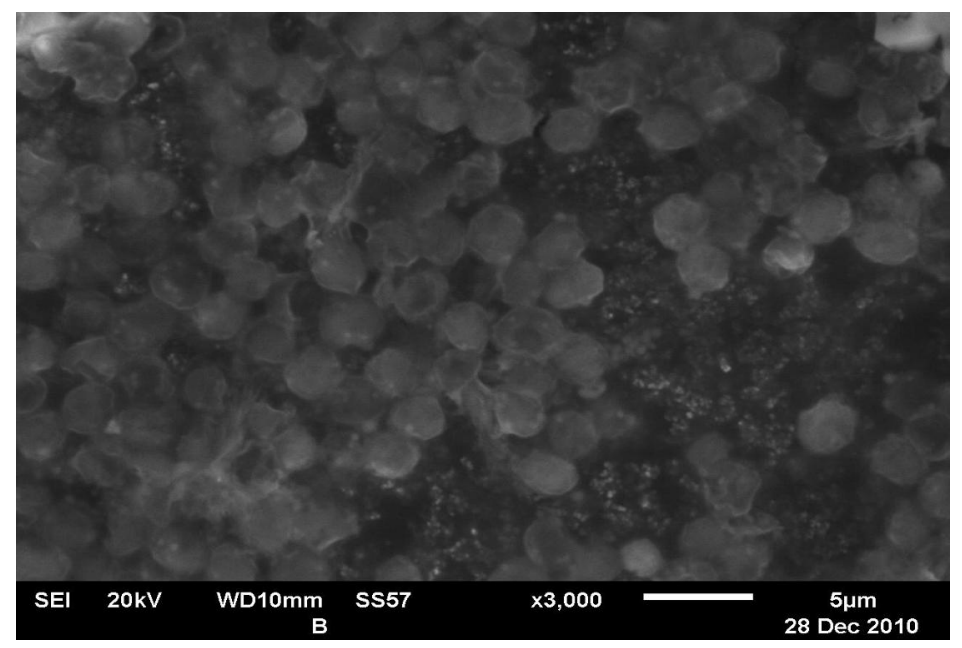

Gambar 3. Sel Botryococcus braunii ukuran 2-3 $\mu \mathrm{m}$ (kontrol).

Figure 3. Botryococcus braunii cells size of 2-3 $\mu \mathrm{m}$ (control).

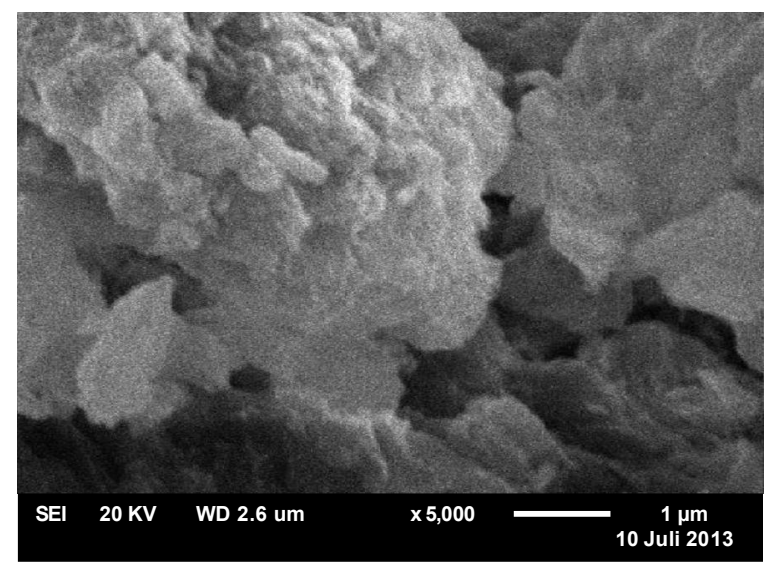

Gambar4. Sel Botryococcus braunii hasil pemecahan menggunakan microwave, frekuensi $2540 \mathrm{MHz}$.

Figure 4. Botryococcus braunii cell treated by microwave, frequency of $2540 \mathrm{MHz}$

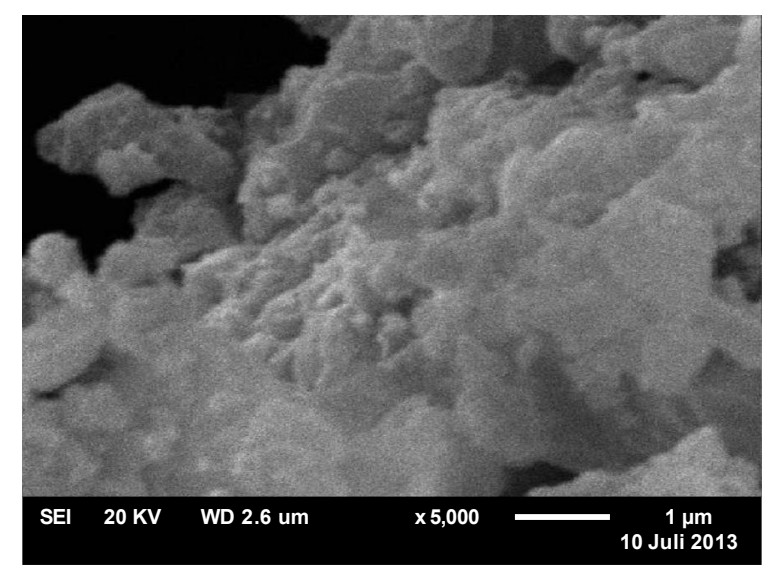

Gambar5. Sel Botryococcus braunii hasil pemecahan menggunakan sonikator, frekuensi $20 \mathrm{KHz}$.

Figure 5. Botryococcus braunii cell treated by sonicator, frequency $20 \mathrm{KHz}$.

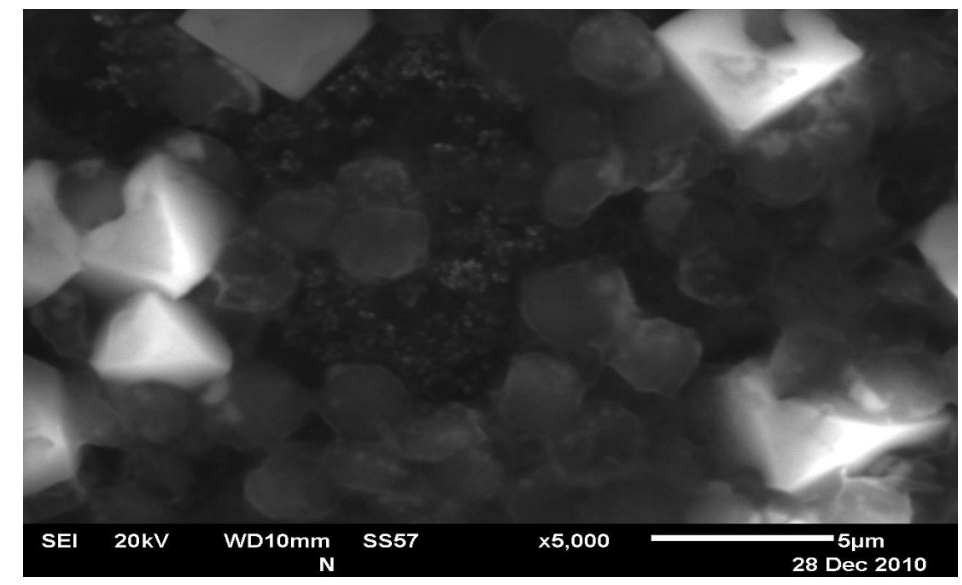

Gambar 6. Sel Nannochloropsis (kontrol) ukuran sel 3-5 $\mu \mathrm{m}$.

Figure 6. Nannochloropsis cell (control) cell size 3-5 $\mu \mathrm{m}$. 


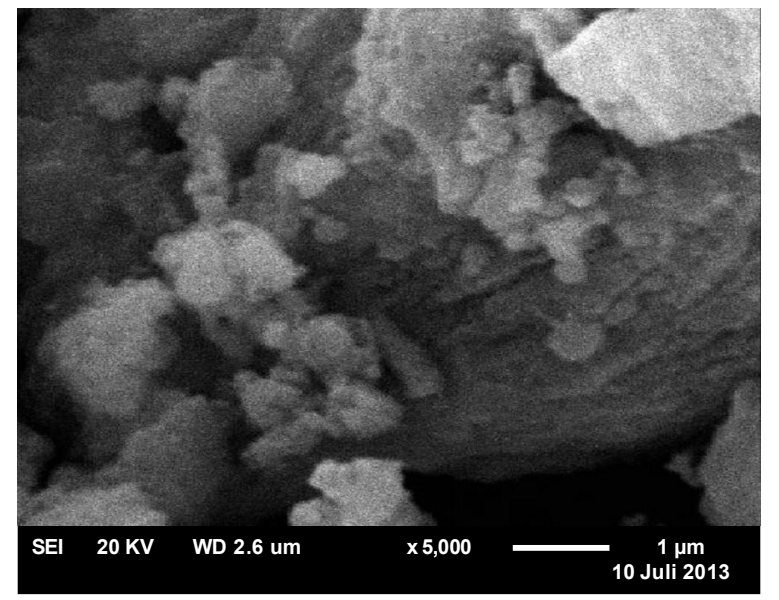

Gambar 7. Sel Nannochloropsis hasil pemecahan menggunakan microwave (frekuensi $2540 \mathrm{MHz}$ ).

Figure 7. Nannochloropsis treated by microwave (frequency of $2540 \mathrm{MHz}$ ).

pada perlakuan kontrol yang tidak dipecah dinding selnya mikroalgae jenis Botryococcus braunii dan Nannochloropsis masih berbentuk bulat-bulat seperti terlihat pada Gambar 3 dan 6.

Gambar SEM (Scanning Electron Microscop) menunjukkan bahwa sel-sel Botryococcus braunii dan Nannochloropsis yang berukuran 2-3 $\mu \mathrm{m}$ dan 3-5 $\mu \mathrm{m}$ telah terpecah dengan sempurna setelah mendapat perlakuan pemecahan dinding sel, sehingga minyak pada bagian vacuola tempat penyimpanan minyak pada sel-sel mikroalga dapat keluar.

\section{Persentase Minyak Mikroalga}

Biomassa kering mikroalga jenis Botryococcus braunii dan Nannochloropsis yang telah dipecah dinding selnya menggunakan perlakuan microwave dan sonikator kemudian diekstrak minyaknya. Hasil minyak yang diperoleh dari 2 jenis mikroalga yaitu

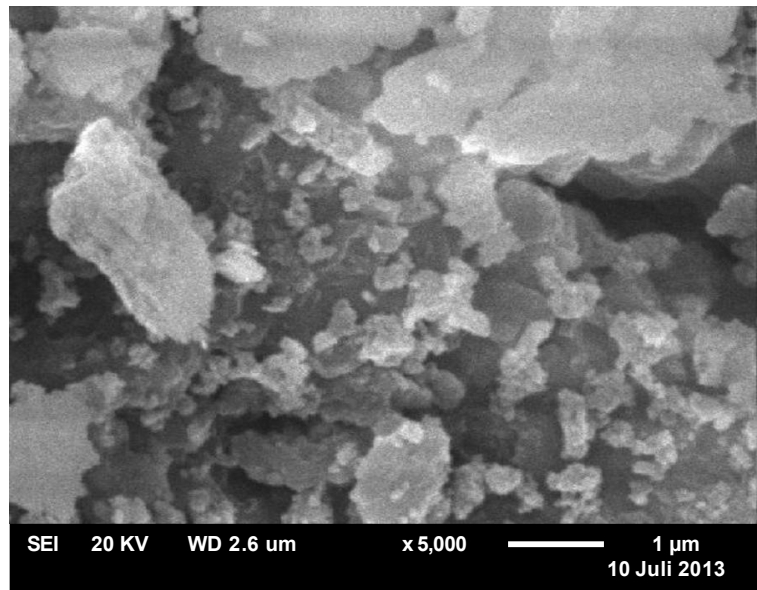

Gambar 8. Sel Nannochloropsis hasil pemecahan menggunakan sonikator (frekuensi 20 $\mathrm{KHz}$ ).

Figure 8. Nannochloropsis cell treated by sonicator (frequency of $20 \mathrm{KHz}$ ).

Botryococcus braunii dan Nannochloropsis dapat dilihat pada Tabel 1. Jumlah minyak mikroalga dengan perlakuan pemecahan dinding sel menggunakan sonikator dan microwave menunjukkan hasil berbeda. Jumlah minyak dari hasil pemecahan dinding sel mikroalga Botryococcus braunii menggunakan sonikator sebesar 22,24\%, sedangkan Nannochloropsis sebesar $11,92 \%$. Hal tersebut karena ukuran sel Botryococcus braunii lebih kecil (2-3 $\mu \mathrm{m})$ dibandingkan Nannochloropsis (4-5 $\mu \mathrm{m})$ sehingga dengan pemanasan suhu $70^{\circ} \mathrm{C}$ dengan frekwensi 20 $\mathrm{KHz}$ dapat menekan sumber minyak yang tersimpan di dalam vacuola yang terdapat didalam selnya. Sebaliknya pada pemecahan dinding sel menggunakan microwave jumlah minyak yang lebih besar diperoleh dari jenis Nannochloropsis yaitu $16,54 \%$ dibandingkan dengan Botryococcus braunii $(7,92 \%)$. Hal ini dimungkinkan karena sinar radiasi microwave dengan frekwensi $2540 \mathrm{MHz}$ pada suhu

Tabel 1. Persentase minyak mikroalgae dengan perlakuan pemecahan dinding sel dan kontrol (\% bobot kering)

Table 1. Oil percentage of microalgae by using cell walls disruption treatments and control (\% dry weight)

\begin{tabular}{lccc}
\hline \multirow{2}{*}{$\begin{array}{c}\text { Spesies Mikroalgael } \\
\text { Mikroalgae Species }\end{array}$} & Kontrol/Control & \multicolumn{2}{c}{ Metode Pemecahan/Breaking Method } \\
\cline { 3 - 4 } & & Sonicator & Microwave \\
\hline Botryococcus braunii & $0.840+0.496$ & $22.24+2.682$ & $7.92+1.945$ \\
Nannochloropsis & $1.540+0.768$ & $11.92+3.063$ & $16.54+2.925$ \\
\hline
\end{tabular}


$90{ }^{\circ} \mathrm{C}$ lebih mudah menembus dinding sel Nannochloropsis yang mempunyai ukuran 3-5 $\mu \mathrm{m}$ dengan permukaan membrane sel yang lebih luas dari Botryococcus braunii. Sedangkan membran dinding sel Botryococcus braunii dengan ukuran lebih kecil (2-3 $\mu \mathrm{m})$ mempunyai luas permukaan sel yang lebih kecil. Pada kontrol tanpa pemecahan dinding sel jumlah minyak yang diperoleh dari 2 jenis mikroalga cukup rendah yaitu Botryococcus braunii $=0,84 \%$ dan Nannochloropsis $=1,54 \%$. Menurut Borowtzka (1992) kelas Chlorophycae termasuk jenis Nannochloropsis mempunyai kandungan minyak berkisar antara 1$70 \%$. Namun demikian kandungan minyak Nannochloropsis pada penelitian ini masih rendah. Hal tersebut dimungkinkan karena proses maserasi dengan $n$-heksana belum sempurna menembus membran vacuola sebagai tempat sumber minyak di dalam sel (Amini, 1999, 2003, 2005). Hal tersebut didukung pernyataan Darwis (2000) dan Susiloningsih (1999) bahwa proses maserasi ekstraksi yang lama akan menghasilkan rendemen minyak yang semakin tinggi. Namun demikian pada penelitian ini maserasi dalam n-heksana yang dilakukan selama 24 jam pada perlakuan kontrol (tanpa pemecahan dinding sel) dari Nannochloropsis dan Botryococcus braunii masih menghasilkan jumlah minyak yang rendah, sehingga untuk mendapatkan minyak dalam jumlah yang lebih besar diperlukan waktu maserasi lebih dari 24 jam.

\section{Kandungan Asam Lemak}

Analisis jenis asam lemak pada penelitian ini dilakukan hanya pada rendemen minyak yang tinggi yaitu dari jenis Botryococcus braunii dengan pemecahan dinding sel menggunakan sonikator dan dari Nannochloropsis dengan pemecahan dinding sel menggunakan microwave. Sebagaimana diketahui bahwa jenis-jenis asam lemak merupakan penyusun utama minyak nabati atau lemak. Asam lemak dapat dibedakan menjadi asam lemak jenuh (saturated fatty acids = SAFA) yaitu asam lemak yang tidak memiliki ikatan rangkap dan asam lemak tidak jenuh

Tabel 2. Hasil analisis asam lemak mikroalga (\%)

Table 2. The results of fatty acid contents of microalgae (\%)

\begin{tabular}{|c|c|c|c|}
\hline No & $\begin{array}{l}\text { Kandungan Asam Lemak/ } \\
\text { Fatty Acid Contents }\end{array}$ & Botryococcus & Nannochloropsis \\
\hline & \multicolumn{3}{|c|}{ Asam lemak jenuh/Saturated fatty acid } \\
\hline 1 & Miristic C14 & 10 & 6 \\
\hline 2 & Stearic C18 & 18 & 21 \\
\hline 3 & Palmitic C16 & 5 & 9 \\
\hline 4 & Behenic C22 & 1 & 1 \\
\hline \multirow[t]{2}{*}{5} & Arachidic $\mathrm{C} 20$ & 4 & 2 \\
\hline & Total & 38 & 39 \\
\hline & \multicolumn{3}{|c|}{ Asam lemak tidak jenuh/Unsaturated fatty acid } \\
\hline 6 & Oleic C18 & 8 & 8 \\
\hline 7 & Vaksenic C14 & 1 & 1 \\
\hline 8 & Palmitoleic C18 1 & 6 & 6 \\
\hline 9 & Linoleic C $18_{2}$ & 9 & 6 \\
\hline 10 & Linolenic C $18_{3}$ & 1 & 2 \\
\hline 11 & Oleic -tetranoic C $18_{4}$ & 0 & 0 \\
\hline 12 & Arachidonic C $2 \mathrm{O}_{4}$ & 5 & 2 \\
\hline 13 & EPA & 4 & 4 \\
\hline \multirow[t]{2}{*}{14} & DHA & 9 & 9 \\
\hline & Total & 43 & 38 \\
\hline 15 & Lain-lain/Others & 20 & 23 \\
\hline
\end{tabular}


monounsaturated fatty acid (MUFA) dan polyunsaturated fatty acid (PUFA) yang memiliki ikatan rangkap. Hasil analisis asam lemak pada jenis Botryococcus braunii dan Nannochloropsis dapat dilihat pada Tabel 2. Jenis asam lemak jenuh (saturated fatty acids) pada Botryococcus braunii terdiri atas asam miristat $10 \%$, asam stearat $18 \%$, palmitat $5 \%$, behenat $1 \%$ dan arachidat $4 \%$ dengan jumlah total $38 \%$. Sedangkan jenis asam lemak jenuh pada Nannochloropsis antara lain asam miristat 6\%, asam stearat $21 \%$, palmitat $9 \%$, behenat $1 \%$ dan arachidat $2 \%$ dengan jumlah total $39 \%$. Asam lemak tidak jenuh (unsaturated fatty acid) dari Botryococcus braunii dan Nannochloropsis diketahui terdiri dari asam oleat, vaksenat, palmitoleat, linoleat, linolenat, arachidonat, EPA dan DHA yang mempunyai proporsi berturut turut 43 dan 38\% (Tabel 2). Meskipun proporsi asam lemak jenuh pada Botryococcus braunii lebih rendah dari asam lemak tidak jenuhnya dan proporsi asam lemak jenuh Nannochloropsis setara dengan asam lemak tidak jenuhnya, namun jenis mikroalgae ini mempunyai peluang untuk dikembangkan sebagai penghasil bahan baku biofuel. Hal ini didukung oleh penelitian Puspita (2009) yang menyatakan bahwa minyak kelapa sawit yang mengandung asam lemak jenuh setara $50 \%$ berpeluang sebagai bahan pembuatan biodiesel.

\section{KESIMPULAN}

Kepadatan sel mikroalgae Botryococcus braunii dan Nannochloropsis yang dikultivasi selama 4 hari pemeliharaan menunjukkan jumlah masing-masing sebesar $\log 7,04 \mathrm{sel} / \mathrm{ml}$ dan $\log 7,15 \mathrm{sel} / \mathrm{ml}$.

Jumlah minyak dengan perlakuan pemecahan dinding sel menggunakan sonikator pada Botryococcus braunii sebesar 22,24\%; dan Nannochloropsis sebesar $11,92 \%$. Sedangkan pada pemecahan dinding sel menggunakan microwave jumlah minyak hasil ekstraksi dari jenis Nannochloropsis sebesar 16,54\% dan Botryococcus braunii sebesar $7,92 \%$. Pada kontrol (tanpa pemecahan dinding sel) jumlah minyak dari 2 jenis mikroalga sangat rendah yaitu Botryococcus braunii 0,84\% dan Nannochloropsis 1,54\%.

Proporsi asam lemak jenuh dari mikroalgae Botryococcus braunii sebesar $38 \%$ yang terdiri dari asam miristat $10 \%$, asam stearat $18 \%$, palmitat $5 \%$, behenat $1 \%$ dan arachidat $4 \%$. Sedangkan pada Nannochloropsis proporsi asam lemak jenuhnya adalah asam miristat $6 \%$, asam stearat $21 \%$, palmitat $9 \%$, behenat $1 \%$ dan arachidat $2 \%$ dengan jumlah total $39 \%$.

\section{DAFTAR PUSTAKA}

Amini. (1999). The structur of I.galbana T-Iso in Studies on the Culture of Isochrysis galbana clone Tahiti. Department of Biological Sciences. Univ. College of Swansea. U.K. p. 114-120.

Amini. (2003). Penelitian Kandungan Asam Lemak pada Ganggang Halus Laut dari Jenis T. iso, Pavlova luteri, dan Tetraselmis, sp. sebagai Pakan Larva Biota Laut. Seminar Nasional Perikanan Indonesia 8-9 Oktober. STP, Jakarta. 10 pp.

Amini. (2004). Pengaruh Umur Ganggang Halus Laut Jenis Chlorella, sp. dan Dunaliella, sp. terhadap Pigmen Klorofil dan Karotenoid sebagai Bahan Baku Makanan Kesehatan. Seminar Nasional \& Temu Usaha, Fakultas Pertanian Universitas Sahid, Jakarta. p. 229-238.

Amini. (2005). Skrining Mikroalgae Penghasil Kandungan Asam Lemak Omega-3. Seminar Nasional Perikanan Indonesia. Makalah Utama. Sekolah Tinggi Perikanan Jakarta. p. 260-275.

Anonim. (2006). Algae oil extraction. www.oilgae.com/ algae/oil/extract/extract.html. diakses tanggal 26 Desember 2006.

AOAC. (1999). Official Methods of Analysis. 13rd ed.Association of Official Analytical Chemist. Washington D.C.

Banerjee, A., Sharma, R., Chisty, Y., \& Banerjee, U.C. (2002). Botryococcus braunii: A renewable source of hydrocarbons and other chemicals. Critical Reviews in Biotechnology. (22)3: 245-279.

Borowitzka, M.A. (1992). Fats, Oils, and Hydrocarbons. Micro-algal. Biotechnology. Section The Algae Cambridge Univ. Press. p. 257-287.

Brown, A.C.,Knights, P.A. \& Conwy, E.1969. Hydrocarbon content and its relationship to physiological state in the green alga Botryococcus braunii. Phytochemistry. 8: $543-547$.

Chisti, Y. (2007). Biodiesel from microalgae. Biotechnology Advances 25. Elsevier Inc.New Zealand p. 294-306

Dayananda, C., Sarada, R., Kumar, V., and Ravishankar, G.A. (2007). Isolation and characterization of hydrocarbon producing green alga Botryococcus braunii from Indian freshwater bodies. Electronic Journal of Biotechnology. 10(1): 80-91.

Darwis, D. (2000). Teknik dasar Laboratorium dalam Penelitian Senyawa Bahan Alam Hayati. Workshop Pengembangan Sumber Daya Manusia dalam Bidang Kimia Organik Bahan Alam Hayati. FMIPA Universitas Andalas Padang. 30 pp.

Fogg, G.E. \& Thake, B. (1987). Algae Culture and Phytoplankton Ecology. Second Edition. The University of Winconsin Press. London. $20 \mathrm{pp}$

Lee, J., Yoo, C., Jun, S., Ahn, C. \& Oh, H. (2010). Comparison of several methods for effective lipid extraction from microalgae. Bioresource Technology, 101: $575-577$.

Lee, A.K., Lewis, D.M., \& Ashman, P.J. (2012). Disruption of microalgal cells for the extraction of lipids for 
biofuels. Australia Biomass and Bioenergy. 46: 89101.

Oh-Hama. T. \& Miyachi, S. (1992). Chlorella: Micro-Algal Biotechnology. In Borowitzka, M.A. and Borowitzka, L.J. Cambridge. Univ. Press.

Panggabean, L.G.M. (1998). Mikroalga: Alternatif pangan dan bahan industri di masa mendatang. Oseana. 13 (1): 19-26.

Puspita, T. (2009). Ekstraksi Minyak Nabati Mikroalga Laut Jenis Botryococcus braunii dan Tetraselmis sp. Menggunakan Pelarut yang Berbeda. Skripsi. FMIPA UIN, Jakarta. 65 pp.

Kabinawa, I.N.K. (2008). Biodiesel energi terbarukan. Warta Pertamina. 9: 31-35.
Kabinawa, I.N.K. (2001). Mikroalga sebagai Sumber Daya Hayati (SDH) Perairan dalam Perspektif Bioteknologi. Puslitbang Bioteknologi LIPI. Bogor. p. 5-13.

Nurhadiati. (2008). Fiksasi $\mathrm{CO}_{2}$ Menggunakan Mikroalga Botryococcus braunii Pada Bioreaktor Up Lift. Skripsi. Fakultas Teknik Kimia Institut Teknologi Bandung.

Susiloningsih, E.K.B. (1999). Kinetika Ekstraksi Minyak Biji Kacang Tanah Utuh dengan Pelarut Heksana. Universita Gajah Mada, Yogyakarta. 20 pp.

Zuhdy \& Sukardi. (2005). Alga sebagai Salah Satu Alternatif Bahan Baku Biodiesel di Indonesia. Institut Teknologi. Surabaya.10 pp 